\title{
Stratified Columnar Epithelium
}

National Cancer Institute

\section{Source}

National Cancer Institute. Stratified Columnar Epithelium. NCI Thesaurus. Code C33620.

Epithelium consisting of multiple layers of cells in which the top layer of cells are taller than they are wide. This epithelium is found in salivary gland ducts. 